\title{
Buying into Development? \\ Brand Aid Forms of Cause-Related Marketing
}

Ponte, Stefano; Richey, Lisa Ann

Document Version

Accepted author manuscript

Published in:

Third World Quarterly

DOI:

10.1080/01436597.2014.868985

Publication date:

2014

License

Unspecified

Citation for published version (APA):

Ponte, S., \& Richey, L. A. (2014). Buying into Development? Brand Aid Forms of Cause-Related Marketing.

Third World Quarterly, 35(1), 65-87. https://doi.org/10.1080/01436597.2014.868985

Link to publication in CBS Research Portal

\section{General rights}

Copyright and moral rights for the publications made accessible in the public portal are retained by the authors and/or other copyright owners and it is a condition of accessing publications that users recognise and abide by the legal requirements associated with these rights.

Take down policy

If you believe that this document breaches copyright please contact us (research.lib@cbs.dk) providing details, and we will remove access to the work immediately and investigate your claim. 


\title{
Buying into Development?: Brand Aid Forms of Cause- Related Marketing
}

\section{Stefano Ponte and Lisa Ann Richey}

Journal article (Post print version)

\begin{abstract}
Cite: Buying into Development?: Brand Aid Forms of Cause-Related Marketing. / Ponte, Stefano; Richey, Lisa Ann. In: Third World Quarterly, Vol. 35, No. 1, 13.02.2014, p. 65-87.

This is an Accepted Manuscript of an article published by Taylor \& Francis in Third World Quarterly on 13 Februarey 2014, available online:

http://www.tandfonline.com/10.1080/01436597.2014.868985
\end{abstract}

Uploaded to Research@CBS: May २०17 


\title{
Buying into Development? Brand Aid Forms of Cause-Related
}

\section{Marketing}

\author{
Stefano Ponte ${ }^{\mathrm{a}}$ and Lisa Ann Richey ${ }^{\mathrm{b}}$ \\ ${ }^{a}$ Department of Business and Politics, Copenhagen Business School, Denmark \\ ${ }^{\mathrm{b}}$ Department of Society and Globalisation, Roskilde University, Denmark
}

Consumers, partnering with corporations and celebrities, are forming new alliances in international development through what we call 'Brand Aid' initiatives. At a time of shifting relationships between public and private aid, commodities are sold as the means for achieving development for recipients and good feelings for consumers simultaneously. In this article, first we formalize our conceptual model of Brand Aid at the triple interface of causes, branded products and celebrities. Then, we conduct a systematic empirical analysis of contemporary Brand Aid initiatives including three in-depth case studies of: 'Win One Give One', TOMS shoes and Product (RED). We argue that these not only use imaginaries of development to sell products to Northern consumers, but also engage in the work of a 'story factory' - producing truths about international development and consumer engagement that make development appear simplified, manageable and marketable. We conclude that, in Brand Aid, the problems themselves and the people who experience them are branded and marketed to Western consumers (through celebritized multi-media story-telling) just as effectively as the products that will 'save' them.

Keywords - brand aid, cause-related marketing, business, consumption, celebrity, development

\section{Introduction}

What links a bottle of vodka with a pair of Emporio Armani (RED) sunglasses, or a pair of canvas shoes with a box of Fruit-Flavored Shapes Transformers? Bono assures us that a percentage of the profits of all (RED) co-branded products goes directly to the Global Fund to Fight HIV/AIDS, TB and Malaria. Dr. Michele Borba, celebrity educator, advises parents that Betty Crocker fruit-flavored snacks can contribute to kids' altruism. Blake Mycoskie identified a development 'need' in Latin America linked to his performance in the US television show, 'The Amazing Race' and launched a youth movement and TOMS shoes. All of these products are marketed through celebrities to consumers who want to shop for a better world. These 
consumers, allied with corporations, are becoming new actors in international development through what we call 'Brand Aid' initiatives. Brand Aid entails specific forms of Cause-Related Marketing (CRM) where the purchase of a product triggers a business donation (typically to a nonprofit organization) for the purpose of solving a social, environmental or animal welfare 'cause'. Unlike other CRM campaigns, Brand Aid initiatives address specific 'international development' causes and involve celebrities in their launch, mediation and/or management.

Brand Aid, the combination of causes, branded products and celebrity, is one of the newest alliances in international development, and it comes at a time of shifting relationships between public and private aid. ${ }^{1}$ Private funding is becoming more important as traditional sources are under stress from the contemporary economic crisis. This is reflected by a historical trend of shifting patterns of resource transfers from North to South. Sources of development financing outside traditional ODA are growing, ${ }^{2}$ and this is shaping the funding and agenda of development. In the contemporary context in which 'economic scarcity' refers not only to the 'lacking' economies in the developing world, but also to their 'donors', the activities of new actors and alliances becomes increasingly prescient. However, the power of Brand Aid for shaping international development is not simply a material one. On the basis of substantial empirical work on CRM initiatives supporting the 30 most recognizable non-profit organizations dealing with 'international needs', a recent article in this journal found that the promotional aspects of partnering with corporations were more important than the actual financial benefits from the CRM engagement. ${ }^{3}$ These findings raise important questions about the role of consumption in funding international development initiatives: in short, if it is not for the money, then why would development organizations benefit from CRM?

To begin to answer this question, we develop a conceptual model of 'Brand Aid', where 'brand' incorporates material value and fantasy. Companies are of course the core actors in branding for profit. Celebrities are personified through their own brands, or personae. And slowly, it is becoming recognized that non-profit organizations working in international development are also branded entities. ${ }^{4}$ Our purpose in this article is to provide a framework to help understanding how development actors such as consumers ${ }^{5}$ and celebrities ${ }^{6}$ overlap in new alliances. We 
also test the model empirically through a systematic study of contemporary Brand Aid initiatives in order to examine its possibilities and limitations.

We distinguish between the selling of ideas together with the 'cargo' of development ${ }^{7}$ and using imaginaries of development to sell products to Northern consumers. We focus on the latter. Development as a commodity for exchange can be linked to trajectories as diverse as selling improved seeds in the Green Revolution or selling condoms through social marketing initiatives for family planning. But the increasing 'privatization of helping' has made engaging in development such a desirable practice, that admission to such a process can be sold to consumers as one might sell entrance tickets to a concert or amusement park. Development outcomes themselves - such as primary education for a child, vaccines provided to a health clinic, or a community well for clean water-become so imbued with symbolic and 'ethical' value that they are used to market consumer goods to Western buyers. Trusted celebrities are important for creating the caring brand that sells development. ${ }^{8}$ Commodities are sold as the means for achieving development for recipients and good feelings for consumers simultaneously. In the process, 'development' becomes ontologically ingrained as 'having the right things.'

Our analysis of Brand Aid initiatives focuses on those with a direct purchasecontribution link. This is a choice that reflects the different kinds of social relations surrounding these forms of CRM. First, the focus on buying a particular product directly links a product with a cause in ways that draw on the awareness raised by decades of activism for fair trade and ethical consumption. But this also pushes the meaning of ethical consumption away from the attributes of the product itself (the social, environmental or animal welfare conditions of its production) and places them onto the worthy cause, as the basis for 'ethical' engagement. ${ }^{9}$ Second, the focus on purchase-linked donation encourages increasing consumption. ${ }^{10}$ As you spend money, purchase products and consume, you are actively 'helping'. Third, in the direct purchase-contribution model, the point of action or engagement is clear and distinct. It is the point of purchase. This clear action for consumers is a way of defining development 'goods' and the entry point for everyday consumers into activism, providing 'development' or just 'helping' needy others. When the purchase has been made, the consumer has completed her/his job in the process of helping, and the 
product itself becomes a marker of that good act. You buy something so that someone else can have something, and imaginaries of development, 'yours' and 'theirs,' are constructed on the basis of these 'things.'

In the next section, we briefly review the current debates on cause-related marketing, celebrity and development. Sections 3 and 4 lay out our conceptual model and methodology. In Section 5, we present four case studies of Brand Aid initiatives, followed by a conclusion.

\section{Cause-Related Marketing, Celebrity and Development}

Brand Aid initiatives are CRM campaigns that employ an international development 'cause' and celebrities as mediators. In earlier work, ${ }^{11}$ we argued that this specific configuration of CRM is new and can be ascribed to the birth of Product (RED) in 2006. However, CRM campaigns have a much longer history and are accompanied by a well-developed literature in business studies, ${ }^{12}$ only recently expanding to development studies. ${ }^{13}$ In its simplest form, CRM is essentially marketing - it is devised to sell a product or service to consumers by highlighting that part of the profit or sale price will be donated to a 'good cause'. The size of the donation is typically linked to the volume of sales during the CRM campaign.

The birth of CRM dates back to the American Express campaigns of the early 1980s, when card-holders were encouraged to use their credit cards in specified campaign periods to support a number of US local causes. ${ }^{14}$ The success of these initiatives led AmEx to legally trademark the term 'cause-related marketing' in 1983, when it began piloting the approach nationally with a three-month campaign to restore the Statue of Liberty. This campaign cost $\$ 4$ million in advertising, raised $\$ 1.7$ million for the cause, and also triggered a 27\% rise in AmEx card use and $45 \%$ increase in new card applications. ${ }^{15}$ The experience demonstrated to AmEx and many other companies after it that they could 'do well by doing good'.

The business studies literature concurs that the number and size of CRM campaigns have experienced a consistently upward trend since their beginning. ${ }^{16}$ Historically, CRM has evolved from being predominantly a one-off tactic to increase sales, to an 
approach aimed at building brand reputation and customer loyalty through deeper long-term commitment linking a brand with a cause organically, and even toward becoming the public face of 'responsibility' for the most advanced companies in this realm. ${ }^{17}$ The explosion of CRM has been fueled by the expansion of social media and the 'word- of-mouth' marketing that it enables. ${ }^{18}$ It has also moved from an almost exclusive focus on local causes to also cover 'distant' ones. Part of the attractiveness of CRM from the point of view of consumers is that it triggers a donation with every purchase. ${ }^{19}$ Einstein ${ }^{20}$ argues that tying a product to a cause not only increases profits but also leads to 'increased sales for the entire line of products connected to the brand ... These sales increases bring in earnings well above the cost of the company's charitable donations.'

Critics question the consequences that CRM campaigns have on power dynamics, distribution and redistribution of resources, portrayals of 'communities in need' and the possibility of stimulating social change. Nickel and Eikenberry, ${ }^{21}$ for example, argue that CRM is especially insidious as it 'creates the appearance of giving back, disguising the fact that it is already based in taking away'. From an analysis of dozens of mostly US-based CRM campaigns, Einstein concludes that most are selfcongratulatory and serve to further corporate interest, while rarely affecting real change, and that they lead to an expectation of return when acting magnanimously because 'when you give you get'. ${ }^{22}$ King's work on the Pink Ribbon breast cancer campaigns to support the Komen Foundation shows how CRM is based on the 'assumption that quick, convenient, and relatively inexpensive acts of giving have nonetheless powerful effects and deep spiritual meaning, $\cdot{ }^{23}$ Critics also argue that CRM campaigns often describe donations terms of 'lives saved' or 'litres of water purified' - making it more difficult to monetize the donation size and highlight the contradictions between profit and donation. They also perpetuate gender stereotypes of both the consumers and the recipients. ${ }^{24}$

CRM with a development cause has also been heavily criticized. Brei and Bohm ${ }^{25}$ analyzed ten brands of bottled water that claim to contribute to campaigns aimed at providing drinking water to 'poor African people,' concluding that these companies are mainly attempting to create a better image for an industry beset by environmental and social criticism. Hawkins suggests that women in the South are typically 
portrayed as being closer to nature, but at the same time unable to fulfill their role of responsible mothers due to environmental conditions. She highlights how CRM campaigns emphasize individual action and market-based solutions to complex issues and how 'everyday lives in the North are constituted as separate from natural environments except through consumption choices, a dangerous idea that constitutes the market as the only route to "participate" in development interventions, caring, and environmentally responsible actions'. ${ }^{26}$

These critiques focus thoughtfully on the relations between profitable companies, products and the causes they claim to support; however they do not engage the role of public approval - a point of important access for celebrity advocates. Celebrities are often found advertising the products, representing the benefits of the cause and cobranding helping as cool, and are important for the 'fit' between a cause and a company. ${ }^{27}$ It is through the celebritization of development information that the cause in CRM becomes marketable.

Celebrity marketing of development causes can be linked to the rise of global celebrity 'do-gooding', ${ }^{28}$ the growing engagement of celebrity politics in the United States ${ }^{29}$ and the United Kingdom, ${ }^{30}$ and to the rise of celebrity diplomacy internationally. ${ }^{31}$ Celebrities are themselves commodities: 'produced, traded and marketed by the media and publicity industries' ${ }^{32}$ They are brands whose images are packaged, bought and sold across national borders. ${ }^{33}$ Celebrities are also 'politics made flesh' - as a both commoditizers and commodities - and an important element of why international development causes are being bought by Western consumers. ${ }^{34}$

Debates on how causes can be wrapped around consumer products with the mediation of celebrity to deliver 'development' have so far been mostly compartmentalized. The business literature has examined CRM, but has mostly focused on its marketing aspects. The emerging literature on celebrities as global actors has focused primarily on famous Hollywood celebrities, not on the aid celebrities whose expertise becomes celebritized and marketed as part of the product of development intervention. ${ }^{35}$ The large political and ethical consumption literature has thoroughly examined the role of fair trade and other labels in promoting (or in failing to promote) 'development', but has so far failed to recognize that CRM and Brand Aid initiatives are moving attention 
away from the social and environmental conditions of production and towards the beneficiaries of causes that have little or no relation to the product itself. In the rest of this article, we argue that there are important overlaps between these aspects that need to be examined systematically. In next section, we develop a conceptual framework for such analysis, followed by a methodological and empirical example of how it can be applied.

\section{Conceptual Model}

In our previous work, ${ }^{36}$ we developed the concept of 'Brand Aid' to describe how branded products are sold as ethical items through their mediation by celebrities who link them to worthy causes in developing countries. Brand Aid, we argued, is 'aid to brands' because it helps sell products and improve a brand's ethical profile and value. It is also 'brands that provide aid' because a proportion of the profit or sales is devoted to helping others.

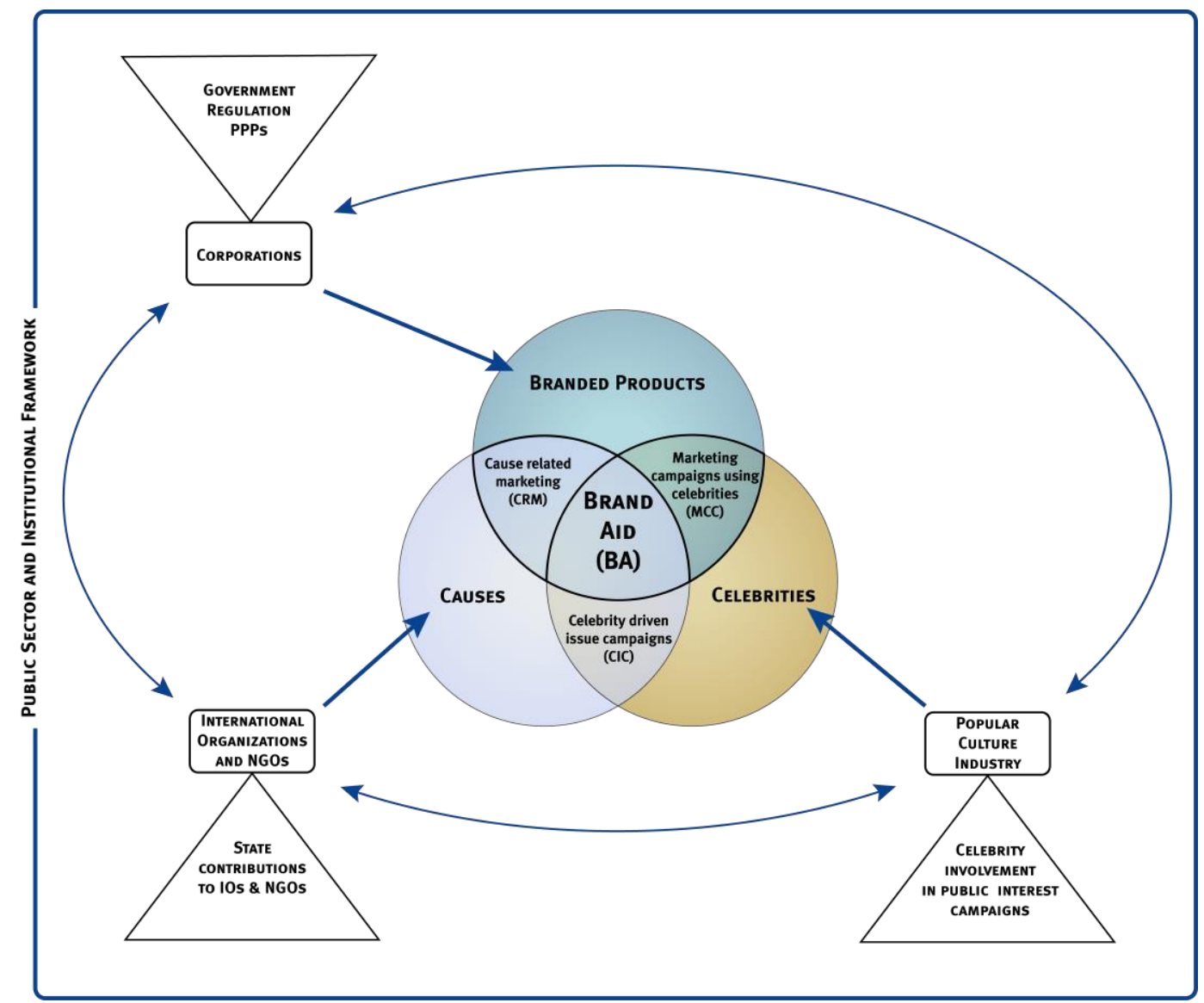

Figure 1. Brand Aid Conceptual Model 
In this article, we introduce a conceptual model as illustrated in Figure 1, where Brand Aid appears at the triple interface of causes, branded products and celebrities. The model also shows other forms of interaction: generic CRM (the combination of branded products and causes); celebrity-driven issue campaigns (the combination of celebrities and causes - for example, George Clooney's Save Darfur campaign); and marketing campaigns using celebrities (the well-established combination of celebrities and branded products). These other categories fall outside the scope of this article, but structured comparisons between them are part of our agenda for future research.

Each of the circles in our conceptual model represents a regime of value that contains both material and symbolic forms. Appadurai ${ }^{37}$ described the arrangements of meanings created by signifying images and objects as 'regimes of value' - constructs of the social imaginary which give significance to experience through discourse. Value for Appadurai refers to both economic or material value and also to the noneconomic categories and understandings of particular commodity arrangements. New imaginaries of development are created in which consumption becomes the mechanism for action and purchase creates partnership between individual consumers, corporations, nonprofits and ultimately beneficiaries in developing countries. The relationship is created, not simply documented, through the discourses, images, narratives and truths communicated as part of Brand Aid.

Regimes of value exist within an institutional framework that constitutes and supports them (see actors and relations in Figure 1 outside the overlapping circles). Traditionally, international development operated through public and private sector interactions between international organizations, NGOs and states. However, as corporations and the popular culture industry become actors in promoting international causes, new alliances are formed and new forms of institutional embedding takes place. In relation to the lower right corner of Figure 1, for example, celebrities engaging in Brand Aid initiatives should be understood through the mediated context of the popular culture industry, which now includes agencies that match the right product/brand/corporation to the right celebrity, or the right international development cause/NGO to the right celebrity, or both. ${ }^{38}$ Celebrities also interact directly with the public sector when they are called to endorse public-service campaigns, or, more controversially, when they move residence to lower taxation 
locations. Similar observations can be made on the interactions between corporations and the public sector (see top left corner in Figure 1; e.g. via public-private partnerships) and between NGOs and their public donors (see lower left corner). Thus, Brand Aid enacts complex regimes of value on the basis of an expanded institutional framework - forging both new alliances and linking new actors in 'development'.

In our model, we are engaging with 'development' as an interactive process of material exchange and conceptual engagement that links the technical and specialized activities practiced in the South by particular 'experts' and 'organizations' with a network and communication media of non-expert publics in the North. Our focus in on what Smith and Yanacopulos ${ }^{39}$ describe as the 'public faces of development' or the various ways in which development organizations convey meanings and representations of the global South and the concept of development itself to a Northern public. Celebrity remains a key component for our conceptual model for its role signifying the communication of development causes specifically to an audience of non-specialists. As described by Brockington in this special issue, the increasing presence of corporate actors in relationships between NGOs and celebrities reflects the rise of CRM initiatives: 'it is good business sense to build relationships with NGOs, particularly if it then results in associations between that business and famous faces'.

\section{Methodology}

In this article, we use the conceptual model of Brand Aid provided in Figure 1 to analyze empirical material documenting contemporary CRM initiatives that have an international development cause and celebrity involvement. Because consumer initiatives are not documented as sources of development financing which would appear in the AidData database, ${ }^{40}$ and many are linked to private corporations whose financial reports are not public information, systematic documentation faced serious challenges. ${ }^{41}$ We settled on a selection process based on existing databases and lists constituted by definition from at least one selection criteria of the Brand $\mathrm{Aid}^{42}$ model.

Our first data search focused on the combination of two elements of Brand Aid: 
'product' and 'cause'. After examining a dozen sites dedicated to CRM, we selected the most comprehensive list of 'new CRM campaigns' compiled by Cause Marketing Forum $(\mathrm{CMF}) .{ }^{43} \mathrm{We}$ conducted a data search covering the period from January 2011 (when CMF started to compile a comprehensive list) to April 2012. The CMF search generated 99 hits that were analyzed by reading the campaign press releases and the websites dedicated to them. In order to qualify as Brand Aid, however, these initiatives need to address not just any cause, but an international development cause. This filter left us with 21 instances - a sizeable minority, given that the CRM literature in business studies typically advises corporations to link their campaigns to local causes. Of these $21 \mathrm{CRM}$ campaigns, seven mentioned a celebrity prominently in their press release and therefore fully qualified as 'Brand Aid' according to our conceptual framework. Of these, we selected the four that were 'transactional' in nature (they required the purchase of a product, not just a 'brand experience' such as visiting a website, leaving a message, or 'liking' a Facebook page) for further analysis.

Our second data search focused on the 'celebrity' involvement criterion and was targeted to identify other initiatives that may have not been captured by the CRM search. We collected data from a prominent set of celebrity newsletters that are sent several times a week to subscribers by the UK-based site 'The Red Pages' (www.theredpages.co.uk), over the same time period covered by the CMF database. This led to the compilation of a list of 1,822 news items on celebrity endorsement, charity work, and involvement in marketing and other events. These items were filtered to assess whether the celebrity was involved in a Brand Aid initiative as defined above. This yielded three new Brand Aid entries and two entries that had already been captured in the CMF database. A final step entailed merging these two filtered databases and eliminating double-entries, which produced a short list of eight case studies (see Table 1). 


\begin{tabular}{|c|c|c|c|c|c|c|}
\hline \multirow{2}{*}{ ID nr. } & \multicolumn{4}{|c|}{ Cause } & \multirow{2}{*}{$\begin{array}{c}\text { Product } \\
\text { Product/brand/company } \\
\end{array}$} & \multirow{2}{*}{$\begin{array}{c}\text { Celebrity } \\
\text { Main celebrities involved }\end{array}$} \\
\hline & Details of international development cause & Nonprofit Involved & Name of Campaign & Donation & & \\
\hline 1 & $\begin{array}{c}\text { Provision of laptop computers to school children in } \\
\text { Rwanda }\end{array}$ & One Laptop Per Child & Win One Give One & $\begin{array}{l}\text { in Africa, up to } 1725 \text { laptops; in the US, } \\
\text { up to } 259 \text { laptops }\end{array}$ & $\begin{array}{c}\text { General Mills (Betty Crocker Fruit } \\
\text { Flavored Snacks) }\end{array}$ & $\begin{array}{l}\text { Dr. Michelle Borba; Nicholas } \\
\text { Negroponte OLPC founder and aid } \\
\text { celebrity }\end{array}$ \\
\hline 2 & Shoes for chilren in need & $\begin{array}{c}\text { TOMS/ } \\
\text { onedaywithoutshoes.com }\end{array}$ & One to One & over 1 million new pars of shoes & TOMS + The Row (shoes) & $\begin{array}{l}\text { Ashley and Mary-Kate Olsen } \\
\text { designed for TOMS; other celebrity } \\
\text { links for the 'one day without shoes' } \\
\text { campaign; Blake Mycoskie, the } \\
\text { founder of TOMS, is a celebrity } \\
\text { himself }\end{array}$ \\
\hline 3 & $\begin{array}{l}\text { AIDS medication to selected Global Fund programs in } \\
\text { Africa }\end{array}$ & $\begin{array}{l}\text { Global Fund to Fight AIDS, } \\
\text { Tuberculosis \& Malaria }\end{array}$ & (Product) RED: Penfolds and Belvedere & $\begin{array}{l}15 \% \text { of sales of two varieties of wine } \\
\text { during promotional periods (Penfolds); } \\
50 \% \text { of profits (Belvedere) }\end{array}$ & Penfolds Wines, Belvedere Vodka & $\begin{array}{l}\text { Bono, Mary J. Blige, Usher and } \\
\text { many other photo-op celebs on } \\
\text { website launch }\end{array}$ \\
\hline 4 & Fight hunger in the Horn of Africa & $\begin{array}{l}\text { Save the Children, International } \\
\text { Rescue Committee and Mercy } \\
\text { Corps }\end{array}$ & We Can Be Heroes & Up to $\$ 1$ million & $\begin{array}{l}\text { DC Comics and Warner Bros. } \\
\text { Entertainment (superhero gadgets) }\end{array}$ & $\begin{array}{l}\text { Superhero characters and US Vice- } \\
\text { Pres. spouse Dr. Jill Biden }\end{array}$ \\
\hline 5 & $\begin{array}{l}\text { Support the healthy development of mothers and } \\
\text { babies while also addressing the basic care needs of } \\
\text { families during crisis situations }\end{array}$ & Save the Children & Johnson's Baby Cares & unknown & $\begin{array}{l}\text { Johnson \& Johnson (Baby Care } \\
\text { packs) }\end{array}$ & Hilary Duff \\
\hline 6 & Helping children through sport in violence prone areas & Fight for Peace & LUTA clothing & unknown & LUTA clothing (boxing clothing) & $\begin{array}{l}\text { Former boxing champion Luke } \\
\text { Dowdney owns the clothing } \\
\text { business; actor Idris Elba supports it }\end{array}$ \\
\hline 7 & Specially deisgned shoes donating funds to charity & OneKid OneWorld & $\begin{array}{c}\text { Celebrity Shoe Design Program for } \\
\text { Charity }\end{array}$ & unknown & ShoeDazzle (shoes) & Kristin Cavallari \\
\hline 8 & $\begin{array}{l}\text { Free T-shirts to children in Africa (and art programs for } \\
\text { low-income children in the U.S.) }\end{array}$ & $\begin{array}{l}\text { Young Audiences Arts for } \\
\text { Learning, Starkey Hearing } \\
\text { Foundation }\end{array}$ & Support the Youth & unknown & $\begin{array}{l}\text { Akomplice Clothing (selected } \\
\text { lines) }\end{array}$ & $\begin{array}{l}\text { NFL star and playmaker Vernon } \\
\text { Davis }\end{array}$ \\
\hline
\end{tabular}

Table 1. Shortlist of Brand Aid initiatives 
In this article we carry out three case studies (see entries 1 to 3 in Table 1) from the short list in order to provide meaningful detail in our analysis. We selected those that represent all three models of business engagement in CRM: the commercial model, the social enterprise model, and the umbrella model. The first case is General Mills' 'Win One Give One' initiative, involving a 'commercial model' in which existing companies select specific products to enhance their ethical value through their link with development causes. The second case is TOMS shoes, which follows a 'social enterprise model' in which social value is the raison d'etre of the business itself. The third case covers the Penfolds and Belvedere Product (RED) campaigns, which are part of the 'umbrella model' where ethical value is mediated and managed by a cobranding initiative. As we have analyzed Product (RED) extensively elsewhere, ${ }^{44}$ we only update and summarize its main features in this article.

\section{Case Studies}

\section{'Win One Give One’: Betty Crocker Fruit Flavored Snacks}

The 'Win One Give One' (WOGO) campaign is an instance of Brand Aid because it combines a cause, a branded product and a celebrity (see Figure 1, central overlap), but with an important twist - the beneficiaries of the cause are simultaneously American children (and their moms) and Rwandan school children. The mechanism enacting Brand Aid in this case is as follows: from 15 November 2011 until 31 July 2012, consumers who entered a UPC code from boxes of General Mills' 'Betty Crocker Fruit Flavored Snacks' ('the branded product') would be registered to win an XO Laptop (the commodity carrying the solution to 'the cause': addressing poor educational infrastructure) provided by an organization founded in 2005 by Nicolas Negroponte ('the celebrity'). Linked to this 'instant win game,' for every 100 UPC codes entered on the website, Betty Crocker Fruit Flavored Snacks pledged to donate one XO laptop to a kid in Africa, up to 1,725 laptops, or in the US, up to 259 laptops. These 'fruit flavored snacks' come in 38 varieties, ranging from 'Fruit-Flavored Shapes My Little Pony' to 'Fruit Gushers Mood Morphers Fruit Punch' ${ }^{45}$ Almost all of the 38 varieties are made from the same ingredients: a combination of concentrated 
pears, corn syrup, modified corn starch, preservatives, and colors of red, yellow and blue. Sugar constitutes approximately half of the total product weight.

What could link fruit-flavored snacks and concerned American mothers with a topdown development techno-fix and 'kids in Africa'? The homepage of the initiative's 'Win \& Give' website centers around a portrait of a young Rwandan boy in a wellpressed school uniform in front of the Rwandan flag. ${ }^{46}$ The child has tightly shaved hair, looks to be around eight years old, and wears an expression of alertness. He is framed with the caption, 'Take a trip to Rwanda with Jean-Luc. See how XO Laptops ${ }^{\mathrm{TM}}$ are making futures brighter'. You can click the bold link under the photo that reads, 'Explore'. To the left side of Jean-Luc is a photo of the computer with a smiling black boy on the screen, and three boxes of fruit flavored snacks. Their caption reads 'Enter a UPC code'. These are linked to the words 'Enter Here!' To the right side is a photograph of a Rwandan boy in the same starched uniform, who may or may not be 'Jean-Luc'. His portrait is superimposed slightly behind a portrait of a smiling, supposedly American, boy in a striped casual, collared shirt with pale skin and freckles, under the caption 'See the impact you can make'. These boys have a link that reads, 'Learn More'. In small text in the right bottom corner of the page is an oldfashioned propeller airplane, pulling a banner that reads, 'Hey kids, this is Advertising'. While the advertising for the fruit snacks is obvious, the subtler, and arguably more hard-sell, approach is for an imaginary of international development delivered through the provision of a commodity.

In terms of the institutional framework within which this Brand Aid initiative operates, it is important to point out that the XO Laptop comes from 'One Laptop per Child,' an international development initiative that has backing from the computer industry and works in more than 30 developing countries, with the idea of producing a durable laptop computer costing only $\$ 100$ that could make technology accessible to developing country children. One Laptop per Child (OLPC) has been controversial since its inception by the development celebrity Nicolas Negroponte. In this development scheme, the low cost laptop would result from a 'tripartite perfect storm' where both business and the public sector play an important role: first, sales would be only to governments and in quantities above one million; second, open-source software would bypass Microsoft software and Intel processors; and third, commodity 
parts would keep the price low. Funding was sought from education ministries on Negroponte's mantra: 'It's an education project, not a technology project.'

One line of criticism has been directed at the technology itself. The best thing about the OLPC computer is that it is inexpensive. However, it has yet to meet the price point of $\$ 100$, and has remained at twice that price. The physical computer was designed to prevent water and soil damage, to be readable in direct sunlight for children who school outside, and to operate on less power consumption to allow for possible solar or crank powering. A scathing technology critique in The Economist described how the laptop has bugs that cause occasional crashes. ${ }^{47}$ Additionally the 'cumbersome operating system' makes it quite difficult, even in a world of abundant electricity and bandwidth, to perform basic activities. This initiative has been characterized in the press as 'a high-profile deal of one man evangelizing top government officials on how he can save their poor children and in the end these politicians abandoned him'. ${ }^{48}$

The politics of global trade and local power relations have also proved problematic for OLPC across its interventions. Consumers in industrialized economies, many of whom still also lack computer access at school, wanted the possibility of buying cheap laptops as well. Countries like Nigeria and Brazil wanted locally - produced laptops. Libya and Nigeria cancelled their informal commitments to purchase the computers when they realized that they were untried, more expensive than $\$ 100$, and were not the only cheap laptops available. Other businesses such as Intel wanted to produce their own cheap laptops and thus, OLPC came to be perceived as creating a monopoly in the market. Another line of criticism has been that OLPC reflects some of the traditionally 'worst practices' in international development. It is a top-down model, developed without consultation on the needs or interests of the local recipients, and it is implemented in a blueprint formula in countries that are extremely diverse.

In Rwanda, where the WOGO computers are donated, OLPC began with a specific deal reached between the country's government in 2007 and OLPC. By March 2012, 80,000 laptops had been donated to schools around the country. The OLPC Coordinator in the Ministry of Education, 'pointed out that the use of laptops on a daily basis in all schools was going to drastically increase with the current 
deployment of servers in schools. They will enable all lessons to be covered through digital courses'. ${ }^{49}$ However, The Economist concluded that 'giving a child a computer does not seem to turn him or her into a future Bill Gates—indeed it does not accomplish anything in particular'. ${ }^{50}$ An evaluation done of OLPC in Peru by the Inter-American Development Bank found that children receiving the 850000 computers in which the government invested \$225 million, did not show any improvement in math or reading. ${ }^{51}$ The IDB report found no evidence that access to a laptop increased motivation or time devoted to homework or reading. ${ }^{52}$

Businessweek declared OLPC a failure in 2007, which it attributed to the project's rejection of the fundamental rule of product development: 'design from the bottom up, not top down. ${ }^{53}$ 'Near-finished prototypes were tested out late in development, brought to village kids as a "gift", ${ }^{54}$ Nonetheless, OLPC continues to operate. In spite of the criticism of the laptop's aesthetic design, awkward software and inappropriate business model for technology diffusion, and with no mention of the relatively high sugar and color content of the supposedly 'healthy' fruit snacks, the links between them as part of a Brand Aid version of CRM were effective.

Whatever the impact on African children, the WOGO initiative assures American mothers that 'any kid can help.' When you click to 'Learn More,' instead of information on OLPC or Rwanda, there are two links: the first is to the 'Kid's Altruism Indicator.' This is described as 'a joint research initiative with Parenting Magazine to uncover kids' views on giving back and helping others. As a component of the partnership, The Parenting Group’s MomConnection ${ }^{\circledR}$ research provided insights on how moms instill altruistic values in their kids.' The questions and 'findings' reported as 'According to Kids: Who do you think you can help?' are interesting. $83 \%$ of kids responded that they could help 'Kids in another country, such as Haiti, Africa [sic], or Chile.' This is only slightly less than those who reported confidence in helping 'kids at my school' or 'my family. ${ }^{, 55}$ The second webpage link takes you to a 'What's your giving style' quiz, to determine your family's giving style and 'receive special tips from Dr. Michele Borba, parenting expert' ${ }^{56}$ After you take the quiz, you can also download a coupon for Betty Crocker Fruit Flavored Snacks.' In WOGO, a first celebrity expert promotes a technological solution to a problem, embedded into the laptop, while a second celebrity expert guarantees that this 
modality of consumption is linked to the development of altruism in American children, and in this development imaginary, giving donors will produce development in villages like Jean-Luc's in Rwanda. Whether the results indicate that you are a 'global do-gooder,' 'neighborhood helper,' or 'project seeker' the same tips appear, including the final suggestion: 'Find easy ways to help others around the world through opportunities such as the Betty Crocker Fruit Flavored Snacks "Win \& Give" campaign.' And with each opportunity, large buttons on the top of the webpage encourage you to 'Print a Coupon,' 'Share on Facebook,' or 'Post on Twitter,' because it is not sufficient to become more empathetic, or 'incorporate giving into your everyday life' but you should share your brand of giving with others.

\section{TOMS Shoes}

TOMS shoes is a social entrepreneurship model in which the cause itself is inextricably linked to the objective of the business. TOMS was founded in May 2006 by Blake Mycoskie ('the celebrity' in our conceptual framework, see Figure 1), who became famous for his participation in the American TV show called 'The Amazing Race.' The genesis story of the brand is that Mycoskie was in Argentina playing polo when he joined a group of foreigners donating used shoes in a village. This was a life changing experience, and thus he started a company that sells an alpargata shoe ("the branded product') inspired by those worn by Argentinian farmers, priced at twice the product value, to permit the company to donate a pair of shoes 'to a child in need' for every pair purchased by the consumer (according to TOMS, shoes are a fundamental resource for protecting children's health, 'the cause'). This 'Buy One, Give One' (BOGO) marketing strategy links the purchase-donation directly with the product and brand of TOMS. It is now advertised as 'One person buys. One person is helped ${ }^{58}$ as the company expanded its product line to include TOMS glasses, which works in partnership with the Seva foundation. ${ }^{59}$ Along with WOGO, TOMS' version of Brand Aid entails the delivery of a commodity to address a development 'cause'.

TOMS operates in an institutional framework where interactions with the public sector are mostly absent, invisible or indirect (see its engagement with schools below); where a complex set of alliances and mechanisms govern shoe production, sale and giving; and where a multitude of supporting 'communities' bring together 
consumers-cum-activists as 'development actors'. TOMS is allied with a variety of 'giving partners,' works in over 60 countries, and 'as of June 2013, TOMS has given more than 10 million pairs of new shoes to children in need' ${ }^{60}$ The 'giving pair' of shoes is most frequently 'a black, unisex canvas slip-on with a sturdy sole,' except in Argentina where TOMS gives shoes 'similar to our colorful Classics,' and in Ethiopia, where they give 'a variety of locally produced shoes'. ${ }^{61}$

Its donation missions, termed 'giving trips,' reward TOMS' staff and contest winners with the opportunity to visit their 'Giving Partners' in developing countries. These trips are well-documented on the blog with colorful photos of young, attractive students, traveling to places like El Salvador to distribute shoes together with organizations like Save the Children. Photos of thin, beautiful university students kneeling at the feet of Third World children to place a shoe, literally, on the feet of the poor, invoke images of cultural Christianity that play on Western consumers' imaginaries of beneficence. $^{62}$

Linked to TOMS is also the 'One for One ${ }^{\text {,TM }}$ Movement, where 'compassionate young people' are 'getting involved' through campus clubs, internships and branded interactions on social media. The most famous TOMS brand activity is the 'One Day Without Shoes' campaign in which supporters go barefoot to 'spread awareness of the impact a pair of shoes can have on a child's life'. On this day, supporters are encouraged by the brand to walk barefoot, photograph their feet, stencil-shirts ('Go without shoes so kids don't have to!' and 'Ask me about my feet'), share the TOMS giving videos, and hold concerts with shoeless musicians.

TOMS effectively manages many of the features of 'new marketing', such as wordby-mouth through social media, real and virtual events, video storytelling, educationcum-marketing, and engaging a movement of consumer-activists. Mycoskie himself is extremely apt at navigating the popular culture industry and its current need for multiproduct and multi-media strategies. He has authored a book Start Something That Matters with a teaching guide that can be downloaded for free. TOMS includes a 'Campus Programs Department' to provide resources for students and teachers who have 'embraced the TOMS philosophy and shared it with their communities inside and outside the classroom. ${ }^{63}$ Detailed instructions are given on how to form a TOMS 
campus club, including registering all events with the company, and hosting at least one event per semester to 'raise awareness of the TOMS story.'

With a catchy slogan and easy to understand truisms, TOMS has become the brand of compassion for many American young people. The author of the popular book and blog, 'Where Am I Wearing' sums up how TOMS fits with American values: 'I've met so many raving TOMS fans that have no idea where TOMS are made [in China]. All they know is that a pair was given away somewhere-probably Africa-because they bought a pair. And that's enough for them to feel swell about their shoes. ${ }^{, 64}$ The development imaginary linking America and Africa is complicated by the inclusion of productive (not merely recipient) 'Others' in China who are actually making TOMS feel-good shoes.

TOMS uses a multi-channel integration strategy to bring awareness to their cause, and to sell their products, framed in terms of inspirational story-telling, not advertising. It relies heavily on its online community for marketing, and has an extensive network on Facebook with over 1.5 million 'likes', including over 4,000 people who have added their own photos or videos to the page. Additionally, TOMS is active on Twitter and has its own YouTube channel. Its charismatic founder Mycoskie has a popular blog that he uses to keep consumers informed on the products and their social impacts, and where he often characterizes himself as the 'chief giver' ${ }^{65} \mathrm{He}$ is also a popular speaker at American church groups, university TOMS clubs and on US television.

TOMS has been critiqued for labour conditions in shoe production in China (where it sources its shoes for sale), Ethiopia and Argentina (where it sources its shoes for donation). The company has responded that it is third-party audited to insure that no child labor is used and fair wages are paid. ${ }^{66}$ In response to the sustainability of shoes for children whose feet grow, TOMS 'strives to set up long-term giving partnerships that allow us to keep giving as children grow'. How often this is practically achieved, given the mobility of families and development partners is not documented. Little is actually known about TOMS giving partners' work, beyond the distribution of shoes, and even less about the actual details of production, volume of sales, and nature of partnerships between the company and its beneficiaries. Other serious critiques are also levied against TOMS because giving in-kind distorts local economies of 
production. ${ }^{67}$ A counter-campaign to TOMS' 'A Day Without Shoes' was launched on the blog 'Good Intentions Are Not Enough' ${ }^{68}$ and entitled 'A Day Without Dignity.' It asked aid workers, the diaspora and people from areas that receive shoe drops and other forms of charity to speak up on blogs, twitter and at school. They posted numerous interventions from critics of the initiative, including videos and photos documenting the widespread availability of shoes in local Third World markets.

Still, Mycoskie has won awards from the Smithsonian Institution in 2007, and the US Secretary of State's award for Corporate Excellence in 2009. ${ }^{69}$ TOMS imaginary of development is one in which growing up barefoot is the primary obstacle to receiving education and avoiding disease: 'Shoes are a fundamental resource for protecting children's health and providing them with opportunity. ${ }^{70}$ TOMS is an award-winning social entreprise model built around cause-related marketing, transmitted in a threeminute video with emotional music, smiling brown children with white saints sitting at their feet. 'Aid-vertising ${ }^{, 71}$ clearly works to get a buy-in from consumers, based on stories they tell themselves.

\section{Product (RED) Belvedere Vodka and Penfolds Wine}

The Product (RED) ${ }^{\mathrm{TM}}$ initiative was launched by Bono the Irish rock star ('the celebrity') at the World Economic Forum in Davos in 2006. Product RED is 'a brand created to raise awareness and money for The Global Fund to Fight AIDS, Tuberculosis and Malaria by teaming up with iconic brands to produce RED-branded products' ${ }^{72}$ With the engagement of iconic brands, such as American Express, Apple, Armani, Gap, and Starbucks ('the branded products'), consumers can help HIV/AIDS patients in Africa ('the cause'). From a RED Bugaboo baby stroller to a RED iPod ${ }^{\mathrm{TM}}$ and from (Starbucks)RED whole bean coffee to a Belvedere special edition RED vodka, a percentage of the profits from the sale of all RED co-branded products is contributed by the 'iconic' partners directly to The Global Fund.

As we have documented in detail elsewhere, ${ }^{73}$ understanding the dynamics of RED is tightly linked to the institutional framework surrounding it, and specifically the actual and perceived roles of public and private donors in financing The Global Fund. The 
Global Fund is an international mechanism to channel aid financing to developing countries, and it controls the second largest pool of donor funds in the world (after the UN itself). Companies that come under the umbrella of RED pay a licensing fee and commit to a multi-year partnership. According to RED's website, as of August 2013, RED had donated nearly $\$ 210$ million to the Global Fund. RED grants are made through the Fund's standard disbursement processes and have been dedicated to the Fund's best-performing programs for AIDS in Africa.

Two of the RED products were captured in our sampling framework. ${ }^{74}$ The first, Belvedere Vodka, has a RED website that can only be accessed after the input of your country and birthday, because viewers must be of legal drinking age in their country, or 18 years old if the country has no drinking age. The vodka company has partnered with RED to produce a Special Edition Bottle the sale of which will donate $50 \%$ of the profits to the Global Fund. The artist and celebrity Usher has teamed up with Belvedere RED Vodka 'to encourage consumers to support programs that offer education and medication on the ground in Africa.'

The second, Penfolds wines from Australia, has a similar contribution and communication model, and has partnered with RED for its Koonunga Hill and Thomas Hyland wines for 'Inspired Wine, Inspi(RED) Purpose'. In June 2012, Penfolds launched a Special Edition bottle, 'for every bottle purchased Penfolds will make a contribution on your behalf to the Global Fund to help eliminate AIDS in Africa. Keep an eye out for this Special Edition pack this summer and help us deliver an AIDS free Generation by $2015,{ }^{75}$ During the promotions period only, Penfolds contributed $15 \%$ of its profits to the Global Fund.

The Brand Aid modality of merging shopping and helping that we described as a new frontier in international development ${ }^{76}$ is maturing into a hybrid institution with likelihood of longer duration. The modalities of engagement within Product RED are expanding: now the model includes CRM, corporate philanthropy (with the new Coca Cola sponsorship which has no direct product link), and activism (now that RED is officially a division of ONE, the international NGO also founded by Bono). The supporting cast of celebrities changes with each event under RED, but the grounding of Bono remains stable. 
Product RED now has two levels of cooperation with business: 'partners' and 'Special Editions'. Additionally, from 1 December 2011, there has been a new partnership between RED and Coca-Cola to 'fund marketing awareness campaigns activated through global Coca-Cola music initiatives and programs.' The company will donate more than $\$ 5$ million over the next four years, with a minimum of $\$ 3$ million to be donated directly to the Global Fund to purchase anti-retroviral medicine and distribute literature. ${ }^{77}$ RED continues to brand celebrity events such as concerts and a virtual AIDS quilt, and the Global Fund has taken up the RED story-telling model in its fundraising campaigns. ${ }^{78}$

\section{Analysis and Conclusion}

A fundamental problem with Brand Aid initiatives is that they are teaching people how to give from a narrowly individualistic and consumption-oriented perspective. Products are manufactured and then linked to 'needs' identified in the developing world, primarily Africa which supplies a convenient trope for 'needy.' In this process, 'development' itself is sold as commodity transfer: development interventions equal donations of commodities, things that needy people need. Companies that both produce these necessary goods and sacrifice their corporate profit to share them with the global poor, invite consumers to 'partner' with them through the purchase of the Brand Aid products. Through real time and virtual events where people come together to share experiences with others who share their deep frame values, ${ }^{79}$ these companies provide not just the commodities themselves, but construct an entire realm in which these products become meaningful - Appadurai's regimes of value. ${ }^{80}$

Large, media-savvy development organizations (primarily international NGOs) 'partner' in constructing these regimes of value for development, resonating with years of promotion of public-private partnerships. 'Private' has now fused with 'corporate', celebrities are becoming the public faces of development, and the distinction between non-profit and for-profit is obfuscated. In this article, we provided a conceptual model that can help examine increasingly complex sets of actors, alliances and relations in development interventions, in the context of a broader institutional framework. We focused on the new overlap between international 
development causes, branded products and 'celebrities' and applied the conceptual model to analyze three case studies of Brand Aid.

Brand Aid provides an easy solution to current crises in linking the global economy to international development - one that enables corporations to brand themselves as 'caring' without substantially changing their normal business practices, while consumers engage in low-cost heroism without meaningfully increasing their awareness of the struggles of people they are supposed to help. In Brand Aid, the problems themselves, whether they be low educational achievement, shoelessness or AIDS, and the people who experience them are branded and marketed to Western consumers through celebritized multi-media story-telling, just as effectively as the products that will 'save' them.

Brand Aid initiatives tend to reduce 'development' to a process of identifying a lack, locating a supplier, providing a commodity, and managing the distribution of the needed commodity to its intended recipients. Our case studies were selected to explore different models of Brand Aid- the commercial business, social enterprise, and umbrella models. Yet, they showed little variation in the imaginary of development as 'providing needed commodities'. In all of these initiatives, products (laptops, shoes, pills) are given to beneficiaries without regard to the underpinning relations of production, consumption or donation. The ethical value is placed exclusively in the realm of the Northern consumer through the purchase of a particular product or the donation within a branded experience. 'Buying' is 'buying into' an imaginary of development in which consumers can make a difference. Making a donation in a branded environment, or sharing a story that will trigger a matching donation by a branded host, is a way of blending the experience of giving and the feeling of empathy with that brand, reflecting calls for corporate philanthropy ${ }^{81}$ to become more strategically related to brand reputation. Thus, engagement in Brand Aid pulls the marketing, corporate philanthropy and brand management sides of business together. Corporate philanthropy becomes shared with the consumer, publicized and celebritized - it is not anonymous, as in past forms. Instead, Brand Aid is embedded in the public relationship between the consumer and the branded product through the mediating role of the celebrity. Given that consumers authorize the development interventions through their purchases, there is no concern 
in Brand Aid for participation of the recipient communities or accountability to these supposed beneficiaries.

Whether business is good for development is an ongoing debate, ${ }^{82}$ and like the larger debates on aid effectiveness, it often suffers from the basic flaw of over-aggregation. ${ }^{83}$ However, the scope and diversity of contemporary Brand Aid initiatives suggest that 'buying into development', at least in some form, is good for business. In this article, we offered a material and a symbolic interpretation of why this may be the case. A material interpretation is that when consumers 'buy into' development through the purchase of CRM products that support international causes, they could encounter opportunities to link material consumption with global production relations in distant places. In this interpretation, Brand Aid could act as a sort of gateway into more substantial changes in consumption patterns as supported by fair trade forms of engagement. However, on the basis of our empirical analysis of contemporary Brand Aid, there are few indications that this is the case. Thus far, Brand Aid has not opened up significant space for greater public debate over the production of products in developing countries or the development interventions that are supposed to 'help' the global poor. If individuals are becoming more aware, through their role as consumers of Brand Aid goods, they are keeping this to themselves.

A symbolic interpretation of why 'buying into development' may be good for business is linked to the increasing involvement of business and corporate philanthropy in financing development aid and in shaping its agenda. Individuals are unlikely to have a 'Gates effect ${ }^{94}$ on development as consumers; however in the aggregation of preferences defined by purchase, Brand Aid may add a democratic perception that links to the current trends of market-led development goals and practices. Consumers could, through their purchases, have the potential to shape aid agendas in ways that are more participatory for Northern publics than the traditional forms of engagement through ODA (which has also never been driven by particularly democratic engagement). Thus far, however, it appears that Brand Aid initiatives tend to drive rather than be driven by consumer's visions of international development. While Brand Aid products are tapping into expanded definitions of 'quality' that include the product's ability to support consumer values (justice and help), they do not seem to have any direct link to the modalities of 'helping' for the causes being 
supported.

Most complicated are the ethical dimensions of the Brand Aid initiatives. As a recent critique of neoliberalism succinctly stated: 'Consumerist activism, development discourse, and pink-ribbon feminism all partake of the liberal fallacy that good will and cooperation and compromise will suffice to fix the intractable problems of poverty and inequality_-problems that are imagined to be static and given, as if outside the realm of history and politicss ${ }^{85}$ All of the contemporary Brand Aid initiatives we analyzed engage in what has been characterized by Flannery ${ }^{86}$ as the work of a 'story factory' - producing truths about international development and consumer engagement that make development appear simplified and manageable and outside of history or politics. As phrased by a critic of TOMS, 'We take the nugget of a story that can be printed on a shoebox and we make up our own story. ${ }^{87}$

When branded products become the mechanisms for action needed to save suffering strangers in our personal stories, we have sold out our values and our noncommodified ways of living those values. Consumption becomes the legitimate place for manifesting meaning, and companies and celebrities are taking on the roles traditionally assigned to philosophers and religious leaders of defining 'the good life'. Negroponte, Mycoskie and Bono define the values around which we are called to mobilize and the branded mechanisms that provide the answers when individuals want to 'take action' on global problems. The way of building relationships, making meaning and living the good life rests on having the right things. In a symmetry that belies equivalences: their development and our development become both based in the things we have.

\section{Acknowledgements}

The authors would like to thank the International Development Research Group at Roskilde University, the participants of the Sustainability Seminar series at Copenhagen Business School, and an extremely helpful reviewer for their feedback on earlier versions of this paper.

\section{Notes}


${ }^{1}$ Richey and Ponte, Brand Aid.

${ }^{2}$ Adelman, 'Global philanthropy and remittances'.

${ }^{3}$ Hawkins, 'A new frontier in development?', 1797.

${ }^{4}$ See Biccum, 'Interrupting the discourse of development'.

${ }^{5}$ Hawkins, 'A new frontier'.

${ }^{6}$ Brockington, 'The Production and construction of celebrity advocacy'.

${ }^{7}$ See the classic Long and Van Der Ploeg, 'Demythologizing planned intervention'.

${ }^{8}$ See Brockington, 'The Production' and also Cameron and Haanstra, 'Development Made Sexy'.

${ }^{9}$ See Richey and Ponte, 'Better (Red) ${ }^{\mathrm{TM}}$ than dead?' and Brand Aid.

${ }^{10}$ See Goodman, 'The mirror of consumption'.

${ }^{11}$ Richey and Ponte, Brand Aid.

${ }^{12}$ See, inter alia, Adkins, Cause-related marketing; Berglind and Nakata, 'Cause-related marketing'; and a recent review in Vanhamme et al., 'To do well by doing good'.

${ }^{13}$ See Hawkins, 'One Pack = One Vaccine'; 'Shopping to save lives'; and 'A new frontier in development'.

${ }^{14}$ Daw, Cause marketing for nonprofits, 3 .

${ }^{15}$ Ibid.

${ }^{16}$ Daw, Cause marketing; CSR Europe, 'Cause Related Marketing'; Einstein, Compassion, Inc.

${ }^{17}$ Daw, Cause marketing.

${ }^{18}$ Einstein, Compassion, Inc.

${ }^{19}$ Integer Group, 'M/A/R/C Research'.

${ }^{20}$ Compassion, Inc., 35.

21 'A critique of the discourse of marketized philanthropy'.

${ }^{22}$ Compassion, Inc., 137.

${ }^{23}$ King, Pink ribbons, Inc., 73.

${ }^{24}$ see Hawkins, 'One Pack'; 'Shopping'; and 'A new frontier'; King, Pink ribbons ; and Richey and Ponte, Brand Aid.

25 'Corporate social responsibility as cultural meaning'.

${ }^{26}$ Hawkins, 'Shopping', 758.

${ }^{27}$ See Hawkins, 'A new frontier', and Brockington, 'The production'.

${ }^{28}$ Littler, 'I feel your pain'.

${ }^{29}$ See for example, Marks and Fisher, 'The King's New Bodies'.

${ }^{30}$ See for example, Street, 'Do celebrity politics and celebrity politicians matter', and 'Celebrity politicians'.

${ }^{31}$ Cooper, Celebrity Diplomacy.

${ }^{32}$ Turner, Understanding celebrity.

${ }^{33}$ Littler, 'Introduction', 1

${ }^{34}$ Boykoff and Goodman, 'Conspicuous redemption?'.

${ }^{35}$ For an exception, see Goodman and Barnes, 'Star/poverty space'.

${ }^{36}$ Richey and Ponte, Brand Aid.

37 'Commodities and the Politics of Value'.

${ }^{38}$ See Brockington, 'The production'.

39 'The public faces of development'.

${ }^{40} \mathrm{http}$ ://aiddata.org/research/releases/

${ }^{41}$ For example, after several trials, we decided that we could not use an internet search focused on a set of words or concepts to establish a 'long-list' of CRM initiatives, due to the many different definitions used for CRM-like initiatives and to the transience of these initiatives on webpages (after CRM initiatives end, they are typically 'disappeared' from companies' websites). Hawkins $2012 \mathrm{~b}$ describes similar data challenges.

${ }^{42}$ To be defined as Brand Aid, initiatives must: (1) be CRM initiatives; (2) involve at least one celebrity; and (3) have a cause related to 'international development' broadly defined (see Richey and Ponte, Brand Aid).

${ }^{43}$ The database used comes from www.causemarketingforum.com, a website established in 2002 with the stated goal of: 'increasing the number of successful company/cause alliances by providing businesses and nonprofit executives with the practical information and connections that they need to succeed'.

${ }^{44}$ Richey and Ponte, Brand Aid.

${ }^{45} \mathrm{http}: / / \mathrm{www}$. generalmills.com/home/brands/baking_products/betty_crocker/brand\%20produc

t\%20list\%20page.aspx\#\{588DE128-522B-4712-9F21-ED8D2EF2CA90\} 
${ }^{46}$ www.winonegiveone.com/Default.aspx.

${ }^{47}$ The Economist, One clunky laptop per child Great idea. Shame about the mediocre computer Jan 4th 2008 www.economist.com/node/10472304.

${ }^{48}$ www.businessweek.com/innovate/NussbaumOnDesign/archives/2007/09/its_time_to_cal.html

${ }^{49}$ The New Times. Rwanda: Project to Distribute 100,000 More Laptops, by Frank Kanyesigye, 6 March 2012: allafrica.com/stories/printable/201203060083.html

${ }^{50}$ The Economist, Education in Peru: Error message: A disappointing return from an investment in computing Apr 7th 2012. From the Print Edition: The Americas.

${ }^{51} \mathrm{http} / / / \mathrm{www}$. iadb.org/en/research-and-data/publication-details,3169.html?pub_id=IDB-WP-304

52 Ibid.

${ }^{53}$ www.businessweek.com/innovate/NussbaumOnDesign/archives/2007/09/its_time_to_cal.html

${ }^{54}$ Ibid.

${ }^{55}$ www.winonegiveone.com_pdf_wingive-parentingresults.pdf

${ }^{56}$ Dr. Michele Borba is 'an internationally renowned educator, award-winning author, and parenting and child adolescent expert' (as written on the product website). Among her most signaled credentials are that she has "appeared more than 100 times as a parent expert on "Today" as well as countless talk shows including "Dr. Phil," "Dateline," "The View," "Dr. Drew," "FOX \& Friends," "The Doctors," "CNN," and "The Early Show".

${ }^{57}$ http://www.toms.com/

${ }^{58} \mathrm{http}: / / \mathrm{www}$. toms.com/eyewear/our-movement

${ }^{59}$ The other 'giving partners' are not listed in TOMS public information, but Partners in Health, Paul Farmer's celebritized NGO has been a partner since 2009.

${ }^{60}$ TOMS One for One Giving Report 2013.

${ }^{61}$ Ethiopia has a competitive footwear industry run by Ethiopians, but this does not figure into the TOMS marketing imaginary.

${ }^{62}$ See Richey and Ponte, Brand Aid for an analysis of how this works in Product RED.

${ }^{63}$ A letter from TOMS Founder and Chief Shoe Giver, Blake Mycoskie, p 3.

${ }^{64}$ www.whereamiwearing.com/?s=Toms \&x=0\&y=0.

${ }^{65} \mathrm{http}: / / \mathrm{www}$. toms.com/blog/

${ }^{66} \mathrm{http}: / /$ apersonaldiaspora.blogspot.it/2011/04/toms-discussion-on-bad-aid.html

${ }^{67}$ See www.goodintents.org/in-kind-donations/a-day- without-dignity.

${ }^{68} \mathrm{http} / / /$ goodintents.org/in-kind-donations/a-day-without-dignity

${ }^{69}$ www.toms.com/blakes-bio

${ }^{70}$ www.toms.com/our-movement-why

${ }^{71}$ As aptly termed by Vivek Nemana on http://aidwatchers.com/2011/04/barefoot-on- broadwaywarning-gross-feet-pics/

${ }^{72}$ See www.joinred.com

${ }^{73}$ Richey and Ponte, Brand Aid. On Product RED, see also Banet-Weiser and Lapsansky, "RED Is the New Black"; Giardina, "One day, one goal", Himmelman and Mupotsa, "(Product) Red: (re)Branding Africa?" and other contributions to the same special issue; Littler, Radical consumption; Wirgau et al., "Is business discourse colonizing philanthropy?"; Youde, "Ethical consumerism or reified neoliberalism?".

${ }^{74}$ All product information from the official website www.joinred.com/partners/\#

${ }^{75}$ www.penfoldsusa.com/?p=1206

${ }^{76}$ Richey \& Ponte, Brand Aid.

77 www.thecoca-colacompany.com/dynamic/press_center/2011/12/red-partnership.html

${ }^{78}$ See Richey, 'Mobilizing for global AIDS treatment'.

${ }^{79}$ Darnton and Kirk, Finding frames.

80 'Commodities'.

${ }^{81}$ Frumkin, Strategic giving.

${ }^{82}$ See Blowfield and Dolan, 'Business as a development agent'.

${ }^{83}$ See Tierney et al., 'More dollars than sense'.

${ }^{84}$ See McGoey, 'The Philanthropic State'.

${ }^{85}$ Hickel, 'Liberalism and the politics of Occupy Wall Street'.

86 'Kiva at Four'.

${ }^{87}$ www. whereamiwearing.com/?s=Toms $\& x=0 \& y=0$

\section{Bibliography}


Adelman, C. "Global philanthropy and remittances: Reinventing foreign aid". The Brown Journal of World Affairs 15 no 2 (2009): 23-33.

Adkins, S. Cause-related marketing: Who cares wins. Boston: ButterworthHeinemann, 1999.

Appadurai, A. "Commodities and the Politics of Value", in The social life of things: Commodities in cultural perspective, edited by A. Appadurai, 3-63. Cambridge: Cambridge University Press, 1986.

Banet- Weiser, S. and C. Lapsansky. "RED Is the New Black: Brand Culture, Consumer Citizenship and Political Possibility". International Journal of Communication 2 (2008) 1248-68.

Berglind M. and C. Nakata. "Cause-related marketing: More buck than bang?" Business Horizons 48 no 3 (2005): 443-453.

Biccum, A. "Interrupting the discourse of development: on a collision course with postcolonial theory". Culture, Theory and Critique 43 (2002): 33-50.

Blowfield, M. and C. Dolan. "Business as a development agent: evidence of possibility and improbability", this special issue.

Boykoff, M. and M. Goodman. "Conspicuous redemption? Reflections on the promises and perils of the "celebritization of climate change". Geoforum 40 no 3 (2009): 395-406.

Brei, V. and S. Bohm. "Corporate social responsibility as cultural meaning: A critique of the marketing of 'ethical' bottled water". Business Ethics: A European Review 20 no 3 (2011): 233-252.

Brockington, D. "The production and construction of celebrity advocacy in international development", this issue.

Cameron, J. and A. Haanstra. "Development Made Sexy: how it happened and what it means". Third World Quarterly 29 no 8 (2008): 1475-1489.

Cooper, A. F. Celebrity Diplomacy. Boulder, CO, Paradigm, 2008.

CSR Europe. "Cause Related Marketing”. Brussels: CSR Europe, 2000.

Darnton, A. and M. Kirk. Finding frames: New ways to engage the UK public in global poverty. London: Bond, 2011.

Daw, J. Cause marketing for nonprofits: Partner for purpose, passion and profits. Hoboken, NJ: Wiley, 2006.

Einstein, M. Compassion, Inc.: How corporate America blurs the line between what we buy, who we are, and those we help. Berkeley, CA: University of California Press, 2011.

Flannery, M. "Kiva at Four". Innovations [Special issue for the Skoll World Forum 2009] (2009): 29-48.

Frumkin, P. Strategic giving: The art and science of philanthropy. Chicago: University of Chicago Press, 2006.

Giardina, M.D. "One day, one goal? PUMA, corporate philanthropy and the cultural politics of brand 'Africa"'. Sport in Society: Cultures, Commerce, Media, Politics 13 no 1 (2010): 130-142.

Goodman, M.K. "The mirror of consumption: Celebritization, developmental consumption, and the shifting cultural politics of fair trade". Geoforum 41 (2010): 104-116.

Goodman, M.K. and C. Barnes. "Star/poverty space: The making of the "development celebrity". Celebrity Studies 2 no 1 (2011): 69-85.

Hawkins, R. "'One Pack = One Vaccine' = one global motherhood? A feminist analysis of ethical consumption". Gender, Place \& Culture: A Journal of 
Feminist Geography 18 no 2 (2011): 235-253.

Hawkins, R. "Shopping to save lives: Gender and environment theories meet ethical consumption”. Geoforum 43 (2012): 750-759.

Hawkins, R. "A new frontier in development? The use of cause-related marketing by international development organisations". Third World Quarterly 33 no 10 (2012): 1783-1801.

Hickel, J. "Liberalism and the politics of Occupy Wall Street". Anthropology of this century no 4 (2012).

Himmelman, N. and D. Mupotsa. "(Product) Red: (re)Branding Africa? Introduction to special issue on RED”. Journal of Pan African Studies 2 no 6 (2008): 1-13.

Integer Group "M/A/R/C Research February 2011: The Checkout Study", 2011.

King, S. Pink ribbons, Inc.: Breast cancer and the politics of philanthropy. Minneapolis, MN, University of Minnesota Press, 2006.

Littler, J. Radical cons:mption: Shopping for change in contemporary culture. Berkshire, UK: Open University Press, 2009.

Littler, J. "Introduction: Celebrity and the transnational". Celebrity Studies 2 no 1 (2011): 1-5.

Littler J. "'I feel your pain': Cosmopolitan charity and the public fashioning of the celebrity soul". Social Semiotics 18 (2008): 237-251.

Long, N. and J. D. Van Der Ploeg. "Demythologizing planned intervention: An actor perspective." Sociologia Ruralis 29 no 3/4 (1989): 226-249.

Marks, M.P. and Z. M. Fischer. "The King's New Bodies: Simulating Consent in the Age of Celebrity". New Political Science 24 no 3 (2002): 371-94.

McGoey, L. "The Philanthropic State: Market-state hybrids in the philanthrocapitalist turn", this special issue.

Nickel, P.M. and A.M. Eikenberry. A critique of the discourse of marketized philanthropy. American Behavioural Scientist 52 no 7 (2009): 974-989.

Richey, L.A. "Mobilizing for global AIDS treatment: Clicking compassion and shopping salvation", Glocal Times/Nordicom Review, Special Issue on Mobilizing communication globally: for what and for whom?" edited by K. Wilkinson and F. Enghel, forthcoming.

Richey, L.A. and S. Ponte. Better (Red) ${ }^{\mathrm{TM}}$ than dead? Celebrities, consumption and international aid. Third World Quarterly 29 no 4 (2008): 711-729.

Richey, L.A. and Ponte, S. Brand Aid: Shopping well to save the world. Minneapolis, MN: University of Minnesota Press, 2011.

Smith, M. and H. Yanacopulos, H. "The public faces of development: An introduction". Journal of International Development 16 no 5 (2004): 657-664.

Street, J. "do celebrity politics and celebrity politicians matter?" The British Journal of Politics and International Relations 14 no 3 (2012): 346-356.

Street, J. "Celebrity politicians: Popular cultural and political representation". British Journal of Politics and International Relations 6 no 4 (2004): 435-452.

Tierney, M.J., D.L. Nielson, D.G. Hawkins, et al. "More dollars than sense: Refining our knowledge of development finance using AidData". World Development 39 no 11 (2011): 1891-1906.

Turner, G. Understanding Celebrity. London: Sage, 2004.

Vanhamme, J., A. Lindgreen, J. Reast, and N. van Popering. "To do well by doing good: Improving corporate image through cause-related marketing". Journal of Business Ethics 109 no 3 (2011): 259-274.

Wirgau, J.S., K.W. Farley, and C. Jensen. "Is business discourse colonizing 
philanthropy? A critical discourse analysis of (PRODUCT)RED”. Voluntas: International Journal of Voluntary and Nonprofit Organizations 21 no 4 (2010): 611- 630 .

Youde, J. "Ethical consumerism or reified neoliberalism? Product (RED) and private funding for public goods". New Political Science 31 no 2 (2009): 201-220. 